\title{
PSIKOEDUKASI POLA ASUH PADA IBU-IBU DI WILAYAH PUSKESMAS KEPUTIH SURABAYA
}

\author{
Yolanda Candra Arintina* \\ *Universitas Airlangga \\ DOI: http://doi.org/10.21009/JPPP.092.03
}

\section{Alamat Korespondensi:}

yolandacandraa@gmail.com

\begin{abstract}
The psychoeducation program regarding parenting style for mothers was conducted as a part of a psychological intervention. This intervention aims to increase the understanding of parenting among mothers in Kenanga Maternal and Child Health Service in Puskesmas Keputih, Surabaya area, by giving Psychoeducation of Parenting. Fourteen mothers were included as the participants in this intervention by using purposive sampling technique. The pretest and posttest questionnaire were given to the subjects to measure the understanding of parenting before and after the intervention. The finding showed that the psychoeducation as the intervention increase the understanding of parenting among mothers in Kenanga Maternal and Child Health Service in Puskesmas Keputih, Surabaya (Asymp. Sig (2-tailed) $0.001<0.05)$. This study led to the suggestion of conducting the intervention in the prospective time with the greater area.
\end{abstract}

Keywords

Parenting, psychoeducation, mothers

\section{Pendahuluan}

Perilaku kriminal tidak hanya dilakukan oleh orang dewasa, namun juga dapat dilakukan oleh anak-anak. Seorang anak berusia 10 tahun, SY, melakukan penganiayaan terhadap teman sekelasnya RA hingga meninggal (Setyawan, 2014). Penganiayaan tersebut dilakukan di kelas dengan disaksikan teman-teman korban dan pelaku. Perilaku agresi juga dilakukan oleh seorang anak berusia 8 tahun, KV, yang memukul teman sekelasnya hingga buta (Romi, 2016). Perilaku-perilaku maladaptif tersebut dapat dipengaruhi oleh beberapa faktor, salah satunya faktor keluarga (Grusec, dalam Budi, 2009).

Keluarga merupakan lembaga pertama dalam kehidupan anak, tempat ia belajar sebagai mahluk sosial. Seorang anak mempelajari cara berperilaku dan bersikap untuk pertama kali dari dalam keluarga. Erikson (dalam Gunarsa \& Gunarsa, 2004) mengatakan bahwa orang tua adalah orang yang paling dekat dengan anak serta gambaran kepribadian seorang anak dipengaruhi oleh orang tua dan lingkungan sekitarnya. Nilai yang terdapat di dalam keluarga akan diambil oleh anak baik secara langsung atau tidak langsung.

Dalam proses tumbuh kembang menjadi manusia, anak mulai dibentuk kepribadiannya oleh keluarganya sejak ia lahir. Pembentukan kepribadian anak diperoleh melalui proses sosialisasi di dalam keluarga yang berlangsung dalam bentuk interaksi antara anggota keluarga. Pemberian perlakuan oleh orangtua kepada anaknya menekankan pada bagaimana mengasuh anak dengan baik. Pada umumnya perlakuan orang tua di dalam mengasuh anak-anaknya diwujudkan dalam bentuk merawat, mengajar, membimbing, dan selahkan waktu untuk bermain dengan anak. 
Menurut Bandura (dalam Santrock, 2002), seorang anak dapat meniru perilaku yang ditunjukkan oleh orang-orang terdekatnya. Apabila cara orang tua mendidik anaknya di rumah dengan baik, maka anak akan berkembang memiliki perilaku yang baik pula. Cara orang tua memperlakukan anak atau yang biasa disebut dengan pola asuh orang tua juga sangat mempengaruhi perilaku anak. Pola asuh orang tua merupakan gaya pengasuhan yang dominan dilakukan oleh orang tua. Terdapat beberapa jenis pola asuh yang biasa dilakukan oleh orang tua kepada anaknya. Pola asuh tersebut adalah pola asuh otoriter, demokratis, dan permisif (permisif mengabaikan dan permisif memanjakan).

Menurut penelitian yang dilakukan Munawir (2016), pola asuh orang tua memiliki pengaruh yang signifikan terhadap perilaku agresif. Pola asuh permisif dan pola asuh otoriter memiliki pengaruh yang positif terhadap perilaku agresif, semakin tinggi pola asuh permisif dan otoriter maka semakin tinggi pula perilaku agresif pada anak. Sebaliknya, semakin rendah pola asuh demokratis maka perilaku agresif anak akan semakin tinggi. Menariknya, pola asuh demokratis memberikan memiliki pengaruh negatif terhadap perilaku agresif, yang mana semakin tinggi pola asuh demokratis, maka perilaku agresif juga akan menurun.

Orang tua terkadang tidak menyadari bahwa pola asuh yang mereka lakukan sangat berpengaruh terhadap perkembangan anak. Seperti halnya yang terjadi pada beberapa keluarga di lingkungan Posyandu Balita Kenanga Kecamatan Keputih. Menurut Kader Posyandu Balita Kenanga, terdapat beberapa keluarga yang memiliki anak-anak usia di atas 5 tahun yang memiliki perilaku dan emosi menyimpang, seperti sering mengamuk hingga berkata-kata kasar dan melakukan kekerasan fisik kepada orang lain.

Terdapat seorang anak berusia 6 tahun yang sering menunjukkan perilaku agresi. Orangtua serta nenek dari anak tersebut cenderung menuruti semua keinginannya dari bayi hingga sekarang karena sangat menyayangi anak tersebut. Menurut mereka itu adalah hal dapat mencegah munculnya perilaku agresif dari anak yang mendapatkan pola asuh kurang tepat. terbaik yang dapat mereka lakukan. Di sisi lain, anak tersebut justru tumbuh menjadi anak yang sering mengganggu tetangga-tetangganya, dan ketika marah ia dapat berbicara kotor dan mengamuk baik kepada orang yang lebih muda maupun lebih tua darinya. Anak tersebut juga tidak segan untuk memukul tetangga yang telah berusia tua.

Kader Posyandu Balita Kenanga juga mengungkapkan bahwa terdapat warga yang memiliki banyak anak, dan di sisi lain kedua orang tuanya bekerja. Kader Posyandu Balita Kenanga sangat menyayangkan hal tersebut dan timbul kekhawatiran bahwa anak-anak tersebut akan kurang terawat dengan baik. Selain itu, terdapat kekhawatiran bahwa anak-anak dengan gaya pengasuhan seperti itu akan dapat mempengaruhi perkembangan anak. Beberapa hal yang telah disebutkan di atas menunjukkan bahwa terdapat kebutuhan bagi warga Posyandu Balita Kenanga Kecamatan Keputih untuk mengetahui bentuk pola asuh yang baik untuk merawat balita-balita mereka agar tidak tumbuh menjadi anak-anak yang berperilaku menyimpang.

Beberapa macam intervensi dilakukan oleh praktisi psikologi di Posyandu Balita Kenanga, salah satunya dengan menggunakan psikoedukasi. Psikoedukasi adalah kegiatan yang dilakukan untuk meningkatkan pemahaman dan atau keterampilan sebagai usaha pencegahan dari munculnya dan atau meluasnya gangguan psikologis di suatu kelompok, komunitas, atau masyarakat (HIMPSI, 2010). Psikoedukasi dapat dilakukan kepada ibu-ibu di Posyandu Balita Kenanga sebagai usaha preventif mencegah munculnya perilaku agresif dari anak yang mendapatkan pola asuh kurang tepat.

$$
\text { Intervensi dengan mengadakan }
$$
psikoedukasi yang mengusung tema Pola Asuh untuk ibu-ibu Posyandu Balita Kenanga bertujuan untuk memberikan pemahaman mengenai pola asuh, meliputi pola asuh yang baik dan kurang baik dilakukan kepada anak, serta dampak dari perlakuan pola asuh yang kurang baik tersebut terhadap perkembangan anak. Psikoedukasi tersebut juga merupakan langkah preventif yang 


\section{Metode Penelitian}

Intervensi ini dilakukan dengan metode kuantitatif dan kualitatif. Metode kuantitatif digunakan untuk mengidentifikasi adanya perubahan informasi yang didapatkan oleh peserta sebelum dan setelah pemberian psikoedukasi. Metode kualitatif digunakan untuk mengumpulkan data awal serta untuk mengumpulkan data dari masing-masing subjek. Intervensi ini menggunakan pendekatan Psikologi Kognitif, yang mana memfokuskan pada peningkatan pemahaman subjek terkait pola asuh, dan diharapkan dapat menerapkan di kehidupannya.

Teknik sampling pada intervensi ini adalah dengan menggunakan purposive sampling, dimana peneliti telah menetapkan kriteria sebelumnya pada subjek yang akan melakukan intervensi. Adapun jumlah sampel yang diberikan intervensi adalah 14 orang ibu-ibu yang terdaftar sebagai anggota Posyandu Balita Kenanga di Kecamatan Keputih, Surabaya.
Alat ukur yang digunakan untuk mengetahui perubahan pemahaman pola asuh pada subjek dilakukan menggunakan Kuesioner Pola Asuh yang dibuat oleh pemeriksa yang berisikan tentang pertanyaan-pertanyaan dengan jawaban subyektif yang dialami oleh masing-masing peserta. Kuesioner tersebut berisikan pertanyaan dengan jawaban yang dapat berubah setelah pemberian pelatihan, serta bertujuan untuk mengetahui sejauh mana pemahaman peserta mengenai materi yang diberikan pemeriksa. Intervensi yang dilakukan pada subjek adalah intervensi yang berupa psikoedukasi yang diadaptasi dari psikoedukasi "Menjadi Orangtua Dambaan Anak" yang disusun oleh UNICEF (2015).

\section{Hasil Penelitian}

Berdasarkan hasil pre-test dan post-test yang dilakukan di awal dan akhir intervensi, ditemukan bahwa terdapat perubahan pemahaman dari subjek penelitian mengenai pola asuh

Tabel 1. Hasil Pengisian Kuesioner

\begin{tabular}{cccc}
\hline NO. & Nama & Total Skor Pre Test & Total Skor Post Test \\
\hline 1. & A & 8 & 10 \\
2. & B & 6 & 7 \\
3. & C & 6 & 8 \\
4. & D & 8 & 9 \\
5. & E & 7 & 8 \\
6. & F & 6 & 8 \\
7. & G & 5 & 6 \\
8. & H & 7 & 8 \\
9. & I & 7 & 9 \\
10. & J & 10 & 11 \\
11. & K & 9 & 11 \\
12. & L & 7 & 8 \\
13. & M & 8 & 11 \\
14. & N & 3 & 7 \\
\hline
\end{tabular}


Berdasarkan dari perbandingan total skor pre test dan post test di atas, terdapat peningkatan pemahaman anggota komunitas. Kemudian dilakukan uji statistik menggunakan hasil pre-test dan post-test tersebut. Uji statistik dilakukan dengan penghitungan analisis data menggunakan uji perbedaan sebelum dan setelah mendapatkan perlakuan. Uji statistik menggunakan program SPSS 20 for Windows. Uji analisis menggunakan uji non-parametrik Wilcoxon Signed Rank Test. Uji non-parametrik dipilih karena jumlah subjek yang terlibat kurang dari 30 orang. Wilcoxon Signed Rank Test digunakan untuk menguji perbedaan variabel pada dua kondisi pada sampel yang sama (Pallant, 2011). Berdasarkan dari perbandingan total skor pre test dan post test di atas, terdapat peningkatan pemahaman anggota komunitas. Kemudian dilakukan uji statistik menggunakan hasil pre-test dan post-test tersebut. Uji statistik dilakukan dengan penghitungan analisis data menggunakan uji perbedaan sebelum dan setelah mendapatkan perlakuan. Uji statistik menggunakan program SPSS 20 for Windows. Uji analisis menggunakan uji non-parametrik Wilcoxon Signed Rank Test. Uji non-parametrik dipilih karena jumlah subjek yang terlibat kurang dari 30 orang. Wilcoxon Signed Rank Test digunakan untuk menguji perbedaan variabel pada dua kondisi pada sampel yang sama (Pallant, 2011).

Uji perbedaan Wilcoxon Signed Rank Test digunakan untuk membedakan pengetahuan mengenai pola asuh sebelum dan setelah mendapatkan perlakuan. Intervensi komunitas yang dilakukan dapat dikatakan berpengaruh apabila terdapat perbedaan signifikan antara hasil pre-test dan post-test. Perlakuan yang memiliki perbedaan signifikan akan memunculkan nilai signifikansi Asymp.Sig (2-tailed) $<0.05$. Hasil uji perbedaan Wilcoxon Signed Rank Test dengan menggunakan SPSS 20 for Windows adalah sebagai berikut:

Tabel 2. Hasil Uji Beda

\begin{tabular}{clc}
\hline Variabel & Pretest-Posttest \\
\hline Pola asuh & $Z$ & -3.359 \\
& Asymp.Sig (2-tailed) & 0.001 \\
\hline
\end{tabular}

Berdasarkan penghitungan uji perbedaan menunjukkan nilai signifikansi 0.001. Hasil uji perbedaan ini menunjukkan Asymp. Sig (2-tailed) $<0.05$ maka "Terdapat perbedaan pengetahuan terkait pola asuh pada anggota Posyandu Anak Kenanga sebelum dan sesudah diberikan psikoedukasi". Berdasarkan hasil observasi yang dilakukan ketika proses intervensi dilakukan, para anggota komunitas cukup antusias dalam menerima psikoedukasi. Para anggota komunitas memperhatikan materi yang disampaikan dan memberikan timbal balik terhadap pertanyaan yang diajukan pemeriksa.

\section{Kesimpulan}

Psikoedukasi yang telah dilaksanakan menunjukkan bahwa anggota komunitas memiliki perbedaan pengetahuan sebelum dan sesudah diberikan psikoedukasi. Hal ini dapat dilihat dari hasil uji statistik yang telah dilakukan yang menunjukkan bahwa anggota komunitas memiliki perbedaan yang signifikan saat sebelum dan sesudah pemberian psikoedukasi. Pemberian psikoedukasi kepada anggota dapat meningkatkan pemahaman mengenai pola asuh dan dampaknya bagi perkembangan anak.

\section{Daftar Pustaka}

Budi, S. Hafsah. (2009). Perilaku Agresif Ditinjau Dari Persepsi Pola Asuh Outhoritharian, Asertivitas, Dan Tahap Perkembangan Remaja Pada Anak Binaan Lembaga Pemasyarakatan Anak Kutoarja Jawa Tengah. Jurnal Humanitas, 6 (1) : 42-55. 
Gunarsa, S, \& Gunarsa, Y.S.D. (2004). Psikologi Perkembangan Anak dan Remaja. Jakarta: Gunung Mulia.

HIMPSI. (2010). Kode Etik Psikologi Indonesia. Jakarta: Pengurus Pusat Himpunan Psikologi Indonesia.

Munawir, M. (2016). Dampak Perbedaan Pola Asuh Terhadap Perilaku Agresif Remaja di SMA 5 Peraya. e-Jurnal Pola Asuh (256).

Pallant, J. (2011). SPSS: Survival Manual. (4th ed.). Sydney: Allen \& Unwin.

Romi. (2016). Anak SD Pukul Teman Sekolahnya Hingga Buta. Didapat dari: http://www.harianterbit.com/hanterdaerah/r ead/2016/04/14/60001/81/20/Anak-SDPukul-Teman-Sekolahnya-Hingga-Buta diakses 1 Januari 2017.
Santrock, J.W. (2002). Life Span Development: Perkembangan Masa Hidup, Edisi 5, Jilid II (Terjemahan Juda Manik \& Achmad Chusairi). Jakarta: Erlangga.

Setyawan, D. (2014). Aksi Penganiayaan Dilakukan di Dalam Kelas dan Disaksikan Teman-Temannya Di Kelas $V$ SDN 9 Makasar, Jakarta Timur. Didapat dari: http://www.kpai.go.id /berita/kpai-anakterlibat-kriminalitas- karena- terinspirasilingkungan -tak-ramah-anak/ diakses 1 Januari 2017.

UNICEF. (2015). Modul untuk Fasilitator: Menjadi Orangtua Dambaan Anak. Didapat dari: $\quad$ http://www. batukarinfo.com/system/files/Modul\%20\%2 $01 \%$ 20parenting\%20skill.pdf diakses pada 27 November 2016 